Francesca Rinaldi, MD

Lisa Federle, MD

Marco Puthenparampil, MD

Paola Perini, MD

Francesca Grassivaro, $\mathrm{MD}, \mathrm{PhD}$

Paolo Gallo, MD, PhD

Neurol Neuroimmunol

Neuroinflamm

2018;5:e420; doi: 10.1212

NXI.0000000000000420

\section{EVIDENCE OF B-CELL DYSREGULATION IN SEVERE CNS INFLAMMATION AFTER \\ ALEMTUZUMAB THERAPY \\ OPEN}

Cases of severely exacerbated CNS inflammation have been described in patients with MS under treatment with alemtuzumab, a pan-lymphocytedepleting anti-CD52 monoclonal antibody., ${ }^{1,2}$ On the basis of the peripheral lymphocyte subset network (higher B-cell and suppressed T-cell counts) ${ }^{2}$ and marked clinical improvement following plasmapheresis and rituximab treatment (anti-CD20 antibody), ${ }^{1}$ a B-cell-driven intrathecal autoimmune reaction was hypothesized.

Case report. On January 2017, 4 months after the first course of alemtuzumab, a 27-year-old woman affected by an aggressive form of relapsing remitting MS referred to our MS Centre with a dramatic acute clinical deterioration.

The patient had been diagnosed with MS in 2011, and since the beginning, the disease presented a severe course, with frequent relapses and increased disability in the first year (Expanded Disability Status Scale [EDSS] $=3.0$ ). For these reasons, natalizumab was started on June 2012, with no further evidence of clinical and neuroradiologic disease activity until November 2015, when the patient decided to plan a pregnancy that was safely carried out on July 2016. Two weeks after delivery, she had a relapse with an increased disability. Cerebral MRI disclosed new gadolinium-enhancing lesions and the reactivation of previous lesions. CSF analysis was performed (figure), and JC virus (JCV)-DNA PCR was negative. Considering the disease course and the high JCV index $(>2.0)$, the patient was treated with alemtuzumab (September 2016).

In January 2017, the patient presented with a severe polysymptomatic relapse with dramatic clinical deterioration (EDSS $=7.5$ ). Brain and spinal cord MRIs revealed several contrast-enhancing lesions (most of which were ring-enhancing lesions) disseminated in the brain and cervical spinal cord (figure). CSF examination was repeated and disclosed a significant qualitative change of the oligoclonal $\mathrm{IgG}$ band pattern in both serum and CSF compared with that
Clinical/Scientific Notes

detected in August 2016 (figure). Before starting rescue therapy, T-cell and B-cell subpopulation analyses were performed in peripheral blood (PB) and CSF. In the $\mathrm{PB}$, the total lymphocyte count was $0.8 \times 10^{9} / \mathrm{L}$; $\mathrm{CD} 45^{+} \mathrm{CD} 19^{+}$cells $\left(\mathrm{B}\right.$ cells) were $0.18 \times 10^{9} / \mathrm{L}$ (22\%); and $\mathrm{CD}^{+} \mathrm{CD}^{+}$( $\mathrm{T}$ cells) cells were 0.14 $\times 10^{\%} / \mathrm{L}(18 \%)$. Almost all (98\%) circulating B cells were $\mathrm{CD} 20^{+}$. No trace of $\mathrm{T}$ follicular regulatory lymphocytes $\left(\mathrm{T}_{\mathrm{FR}}, \mathrm{CD} 3{ }^{+} \mathrm{CD} 4{ }^{+} \mathrm{CD} 127^{\mathrm{dim}} \mathrm{CD} 25^{+} \mathrm{CXC}\right.$ $\mathrm{R} 5^{+} \mathrm{PD}^{+}$) could be found in blood and CSF, in front of detectable $\mathrm{T}$ follicular helper lymphocytes $\left(\mathrm{T}_{\mathrm{FH}}, \mathrm{CD} 3{ }^{+} \mathrm{CD} 4^{+} \mathrm{CD} 127^{+} \mathrm{CD} 25^{-} \mathrm{CXCR} 5^{+} \mathrm{PD} 1^{+}\right)$ (figure).

In the CSF, B cells represented $12.5 \%$ of all lymphocytes, of which $40 \%$ were CD20 ${ }^{-}$and displayed high values of physical parameters, suggesting an active state. Moreover, 48\% expressed high levels of CD38, and $61 \%$ (vs $4 \%$ of peripheral B cells) expressed the activation marker CD83, recently demonstrated to play a role during germinal center maturation. ${ }^{3}$

Despite plasmapheresis (5 sessions), the patient continued to deteriorate, and 6 days of high-dose IV methylprednisolone (1 g/d IV) yielded only a very mild clinical improvement. Two weeks later, the patient had a further worsening, and brain MRI disclosed numerous ring-enhanced lesions. The patient had no signs or symptoms of infectious disease, and detailed immunologic and microbiologic screenings in blood and CSF gave negative results. The search for Epstein-Barr virus DNA in blood and CSF by means of reverse transcription PCR was also negative. The patient had no further autoimmune pathologies. Given the malignant course of the disease, the autologous stem cell transplantation was planned.

Discussion. Our case adds new important observations that may shed light on the immunopathologic process occurring in patients with MS who develop severe CNS inflammation following alemtuzumab therapy. Indeed, our findings converge to indicate a primary B-cell-mediated pathology triggered by the therapy. First, the appearance of new IgG bands in serum and CSF implies the activation and maturation of B-cell clones both in the periphery and in the CNS. Second, the presence of $\mathrm{T}_{\mathrm{FH}}$ (a lymphocyte subpopulation that plays a pivotal role in peripheral 

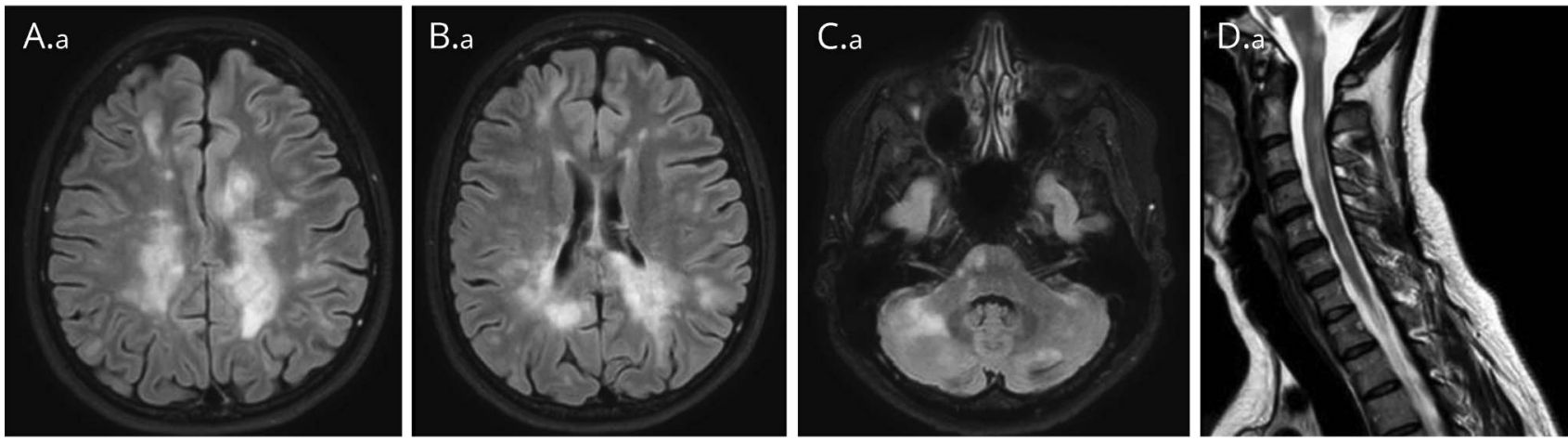

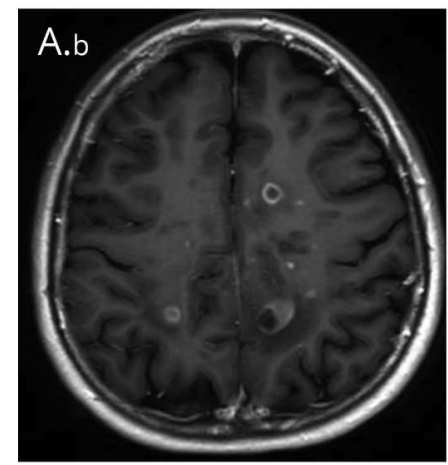

$\mathrm{E}$

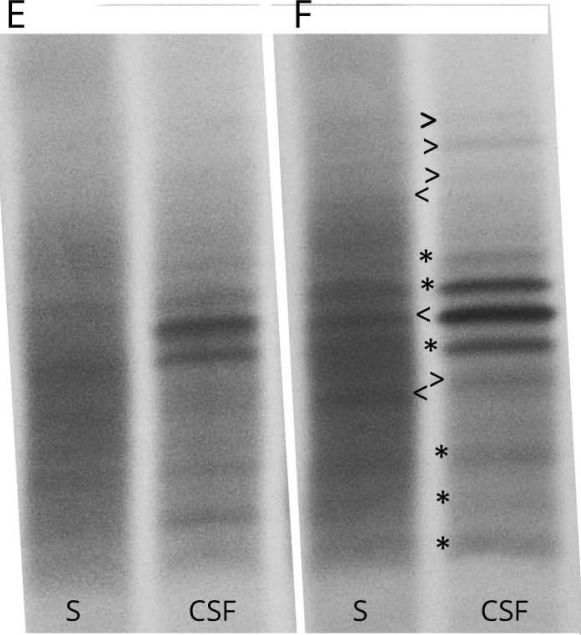

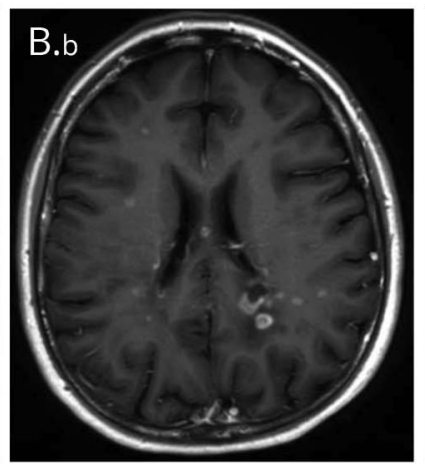
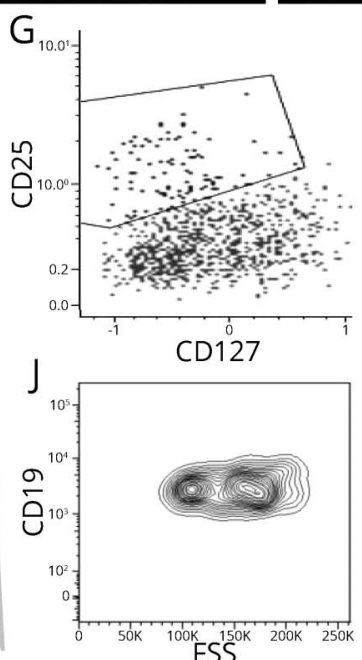
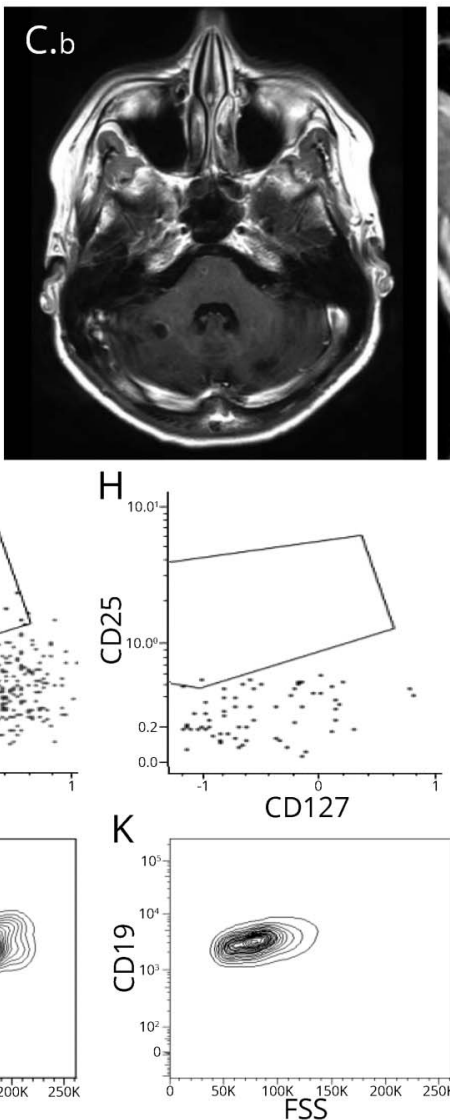
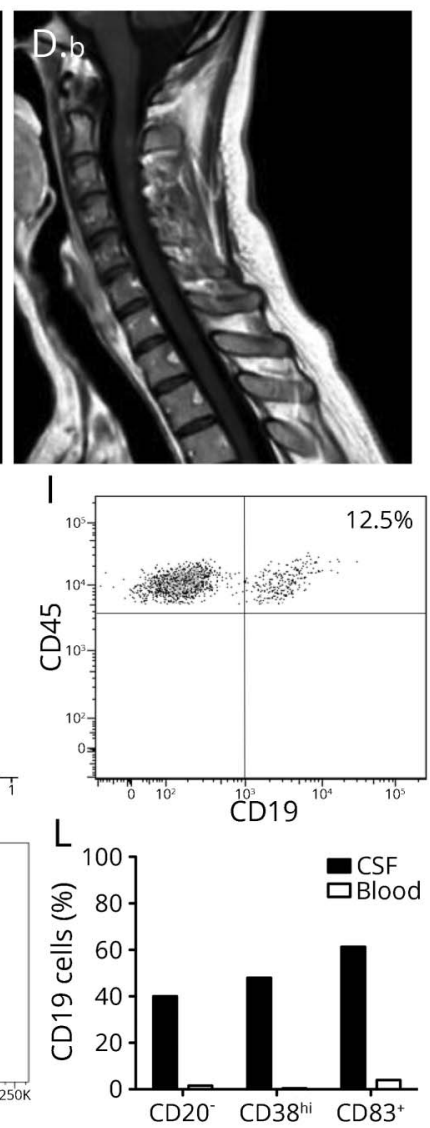

Brain (A.a-C.a = fluid-attenuated inversion recovery sequences, A.b-C.b = postcontrast T1 sequences) and cervical spinal cord (D.a $=$ T2-weighted sequences, D.b = postcontrast T1 sequences) MRI imaging disclosed several active white matter lesions, many with ring-enhanced morphology. (E, $F$ ) IgG isoelectric focusing of paired serum (S) and CSF samples. Compared with the bands detected in August 2016 (E and * in F), during the episode of CNS inflammation following the first alemtuzumab course (February 2017, F), new serum- $(<)$ or CSF- $(>)$ restricted lgG oligoclonal bands were identified. Of interest, a CSF-restricted IgG band detected in August 2016 was found to be mirrored by a serum band in February 2017. (G, H) Analysis of T-helper $\left(\mathrm{CD} 45^{+} \mathrm{CD}^{+} \mathrm{CD}^{+}\right)$cell subsets in the peripheral blood disclosed an almost complete suppression of $\mathrm{T}_{\mathrm{FR}}\left(\mathrm{CXCR} 5^{+} \mathrm{PD} 1{ }^{+} \mathrm{CD} 25^{+} \mathrm{CD} 127 \mathrm{dim}\right)$ lymphocytes in the presence of detectable $\mathrm{T}_{\mathrm{FH}}$ (CXCR5 $\left.{ }^{+} \mathrm{PD} 1^{+} \mathrm{CD} 25^{-} \mathrm{CD} 127^{+}\right), \mathrm{T}_{\text {reg }}$ (CXCR5 $\left.{ }^{-} \mathrm{CD} 25^{+} \mathrm{CD} 127 \mathrm{dim}\right)$, and T-helper (CXCR5 ${ }^{-} \mathrm{CD} 25^{-} \mathrm{CD} 127^{+}$) cells. (I) Plot shows the proportion of CSF B cells (CD45 $\left.{ }^{+} \mathrm{CD} 19^{+}, 12.5 \%\right)$ over the total CD45 leukocyte population (almost all constituted by lymphocytes). (J, K) CSF B cells (J) showed higher values on physical parameters compared with peripheral B cells (K), suggesting an activated status. (L) Compared with peripheral B cells, CSF $B$ cells displayed significant differences in the expression of CD20, CD38, and CD83, suggesting a plasmablast/plasmacells phenotype.

follicular reaction $)^{4}$ along with the absence of $\mathrm{T}_{\mathrm{FR}}$ (that overlook B-cell maturation in the germinal center) $)^{5}$ suggests an imbalanced $\mathrm{T}_{\mathrm{FH}} / \mathrm{T}_{\mathrm{FR}}$ ratio and, thus, a dysregulated follicular reaction. Third, the number and the phenotypic profile of CSF B cells point out to an abnormal proliferation of plasmablasts/plasmacells ${ }^{6}$ within the CNS. Moreover, all these observations were acquired in the time frame in which peripheral B-cell repopulation occurs after alemtuzumab infusion.?

In some patients, the mismatched reconstitution of $\mathrm{B}$ and $\mathrm{T}$ lymphocytes following alemtuzumab likely opens up to a potentially dangerous time window where autoreactive B-cell clones proliferate in the 
absence of the appropriate T-cell control. Whether this disorder is an MS rebound or a new CNS inflammatory entity needs to be studied in larger number of subjects. Considering that alemtuzumab is highly effective in the majority of the treated patients, multicentre studies aimed at identifying those who are susceptible to develop severe alemtuzumab-induced CNS inflammation are urgently needed.

From the Multiple Sclerosis Centre, University Hospital, Department of Neuroscience DNS, University of Padova, Italy.

Author contributions: Francesca Rinaldi: drafting/revising the manuscript and analysis or interpretation of data. Lisa Federle: drafting revising the manuscript, analysis or interpretation of data, and acquisition of data. Marco Puthenparampil: drafting/revising the manuscript, study concept or design, analysis or interpretation of data, and acquisition of data. Paola Perini: drafting/revising the manuscript and analysis or interpretation of data. Francesca Grassivaro: drafting/revising the manuscript, study concept or design, analysis or interpretation of data, and acquisition of data. Paolo Gallo: drafting/ revising the manuscript, study concept or design, and analysis or interpretation of data.

Acknowledgment: The authors thank Dr. Lucia Rossi, of the Virology Section of the Department of Molecular Medicine, University of Padua, for EBV DNA testing in blood and CSF.

Study funding: No targeted funding reported.

Disclosure: F. Rinaldi served on the scientific advisory board of Biogen and received travel funding and speaker honoraria from Merck Serono, Biogen, Sanofi-Aventis, Teva, Sanofi Genzyme, and Novartis. L. Federle received travel funding and/or speaker honoraria from Novartis, Merck Serono, Biogen, Sanofi-Aventis, Bayer Schering, Almirall, Genzyme, and Teva. M. Puthenparampil received travel funding from Novartis, Genzyme, Biogen, Teva, Almirall, and Sanofi-Aventis. P. Perini consulted for Merck Serono, Biogen, and Teva; received travel funding and/or speaker honoraria from BiogenDompe, Sanofi-Aventis, and Merck Serono. F. Grassivaro reports no disclosures. P. Gallo served on the scientific advisory board of Biogen, Merck Serono, Bayer Schering, Sanofi-Aventis, and Novartis; received travel funding andlor speaker honoraria from Biogen, Merck
Serono, Sanofi-Aventis, and Novartis; and received research support from Biogen, Bayer Shering, Sanofi-Aventis, Novartis, Italian Ministry of Public Health, and the University of Padova. Go to Neurology.org/nn for full disclosure forms. The Article Processing Charge was funded by the Department of Neuroscience.

This is an open access article distributed under the terms of the Creative Commons Attribution-Non Commercial-NoDerivatives License 4.0 (CC BY-NC-ND), which permits downloading and sharing the work provided it is properly cited. The work cannot be changed in any way or used commercially without permission from the journal.

Received July 7, 2017. Accepted in final form September 11, 2017.

Correspondence to Dr. Puthenparampil: marco.puthenparampil@ phd.unipd.it

1. Haghikia A, Dendrou CA, Schneider R, et al. Severe B-cellmediated CNS disease secondary to alemtuzumab therapy. Lancet Neurol 2017;16:104-106.

2. Barton J, Hardy TA, Riminton S, et al. Tumefactive demyelination following treatment for relapsing multiple sclerosis with alemtuzumab. Neurology 2017;88:1004-1006.

3. Krzyzak L, Seitz C, Urbat A, et al. CD83 modulates B cell activation and germinal center responses. J Immunol 2016; 196:3581-3594.

4. Fan X, Jin T, Zhao S, et al. Circulating CCR7+ICOS+ memory $\mathrm{T}$ follicular helper cells in patients with multiple sclerosis. PLoS One 2015;10:e0134523.

5. Dhaeze T, Peelen E, Hombrouck A, et al. Circulating follicular regulatory $\mathrm{T}$ cells are defective in multiple sclerosis. J Immunol 2015;195:832-840.

6. Jones AP, Kermode AG, Lucas RM, Carroll WM, Nolan D, Hart PH. Circulating immune cells in multiple sclerosis. Clin Exp Immunol 2017;187:193-203.

7. Hill-Cawthorne GA, Button T, Tuohy O, et al. Long term lymphocyte reconstitution after alemtuzumab treatment of multiple sclerosis. J Neurol Neurosurg Psychiatry 2012;83: 298-304. 


\section{Neurology \\ Neuroimmunology \& Neuroinflammation}

\section{Evidence of B-cell dysregulation in severe CNS inflammation after alemtuzumab therapy \\ Francesca Rinaldi, Lisa Federle, Marco Puthenparampil, et al. \\ Neurol Neuroimmunol Neuroinflamm 2018;5; \\ DOI 10.1212/NXI.0000000000000420}

This information is current as of December 14, 2017

Updated Information \&

Services

References

Subspecialty Collections

Permissions \& Licensing

Reprints including high resolution figures, can be found at:

http://nn.neurology.org/content/5/1/e420.full.html

This article cites 7 articles, 3 of which you can access for free at: http://nn.neurology.org/content/5/1/e420.full.html\#\#ref-list-1

This article, along with others on similar topics, appears in the following collection(s):

Cerebrospinal Fluid

http://nn.neurology.org//cgi/collection/cerebrospinal_fluid

Multiple sclerosis

http://nn.neurology.org//cgi/collection/multiple_sclerosis

Information about reproducing this article in parts (figures,tables) or in its entirety can be found online at:

http://nn.neurology.org/misc/about.xhtml\#permissions

Information about ordering reprints can be found online: http://nn.neurology.org/misc/addir.xhtml\#reprintsus

Neurol Neuroimmunol Neuroinflamm is an official journal of the American Academy of Neurology.

Published since April 2014, it is an open-access, online-only, continuous publication journal. Copyright

Copyright (C) 2017 The Author(s). Published by Wolters Kluwer Health, Inc. on behalf of the American

Academy of Neurology.. All rights reserved. Online ISSN: 2332-7812.

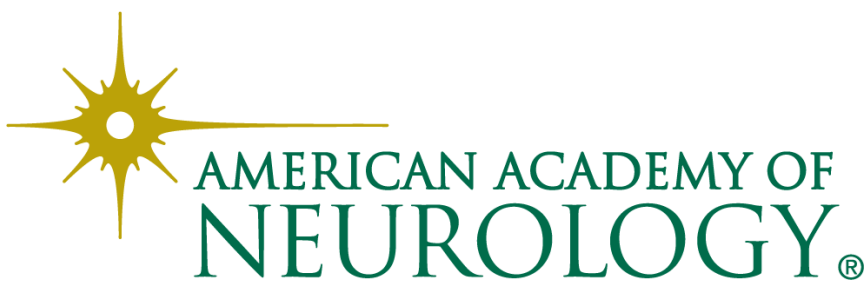

